\title{
Revisiting human liver anatomy: dynamic watershed theory
}

\author{
Rong Liu", Yang Wang", Xiu-Ping Zhang" \\ Faculty of Hepato-Biliary-Pancreatic Surgery, The First Medical Center of Chinese People's Liberation Army (PLA) General Hospital, Beijing, \\ China \\ "These authors contributed equally to this work. \\ Correspondence to: Rong Liu, MD. Faculty of Hepato-Biliary-Pancreatic Surgery, The First Medical Center of Chinese People's Liberation Army (PLA) \\ General Hospital, 28 Fuxing Road, Beijing 100853, China. Email: liurong301@126.com.
}

Submitted Aug 14, 2020. Accepted for publication Sep 07, 2020.

doi: 10.21037/hbsn-20-666

View this article at: http://dx.doi.org/10.21037/hbsn-20-666

\section{The development of hepatic anatomy and its influence on hepatic surgery}

The development of liver anatomy has occurred over hundreds of years, and a mature liver anatomy theory has been formed that was proposed by Couinaud, dividing the liver into 8 segments. However, many scholars have put forward opinions different from the "8 segments" theory (1).

Summing up the previous contributions, we can find several characteristics: (I) all liver anatomical models and vascular and biliary tract models are static in vitro models; and (II) scholars from various countries make use of various anatomical markers on the surface and inside of the liver to divide the liver into multiple independent functional units, namely liver segments, each of which has its own blood supply and drainage channels.

The direction of liver surgery has changed from nonanatomical resection to anatomical resection with changing anatomy. Theoretically, liver anatomical resection has several characteristics on the basis of the "8 segments" theory. (I) The metastasis of hepatocellular carcinoma spreads mainly along the segment portal vein, and intrahepatic bile duct stones are also distributed along the bile duct of the hepatic segment; therefore the lesion can be removed more thoroughly by anatomical resection; (II) there is an avascular area between liver segments; therefore, intraoperative bleeding can be better controlled during liver resection; (III) the different liver segments are essentially not related to each other. As independent functional units, if a liver segment is not completely resected, the affiliated residual liver segment may suffer ischemic necrosis or blood stasis due to insufficient blood supply or blocked outflow, while if a liver segment is completely resected, the surrounding liver segment will not be affected (2).

After extensive clinical practice, we found many phenomena that could not be explained by the 8 -segment theory (3).

(I) The liver volume enlargement after associating liver partition and portal vein ligation for staged hepatectomy (ALPPS) are larger than that after portal vein ligation.

(II) During hemi-hepatectomy, the amount of blood loss after half Pringle maneuver was significantly more than that after whole Pringle maneuver (4).

(III) After embolization of left or right hepatic artery, postoperative angiography reexamination showed that the distal artery on the embolized side resumed blood supply even after the hepatoduodenal ligament was dissected and the perihepatic ligament was free (5).

(IV) The resection of one hepatic vein will cause the blood stasis of drainage area for only a period of time, because the potential outflow tract will be opened, allowing the blood flow status of the liver to form a new equilibrium state (6).

\section{"Static trunk type" and "Dynamic watershed type"}

Traditional liver segment anatomy can be described as "trunk" structure. The main portal vein can be seen as the tree trunk, the portal vein of every segment can be seen as the branch of the trunk, and the blood of every segment is mainly supplied by the portal vein of the segment; there is no communication branch between the liver segments. Traditional liver segment anatomy regards the liver 
segment as an independent functional unit, which to a certain extent ignores the relationship between the liver segments and between each segment and the whole liver, making every segment relatively isolated. The result of this theory is that surgeons are more inclined to treat the liver segment as an independent unit, diseases are distinguished by the liver segment, and surgery is also performed on the liver segment. This weakens the status of the liver as an independent organ.

After extensive clinical practice and summary, we believe that the relationship between liver segments should not be ignored, and the liver should be dissected as a whole organ. Compared with the "trunk type" theory, the inflow and outflow of blood in the liver more closely resemble the process of a river flowing through the land and eventually into the sea. The land around the river is irrigated jointly by adjacent tributaries, and the irrigation amount of different tributaries in this area is related to the distance to this area. Once a tributary is blocked and the water supply in the region is insufficient, other tributaries in the region will adapt to meet the irrigation needs of the region. However, if one tributary is blocked, it will cause a short-term stasis in the area, but as the adaptability of other tributaries changes, after this time window, the water in this area can also be drained through other adjacent tributaries and finally reach a new equilibrium state.

\section{The concept of "dynamic watershed theory"}

Liver dynamic watershed theory is used to redefine the distribution of blood vessels and blood flow in the liver and to change the description of blood vessels and blood flow in the liver from the traditional static trunk type to the dynamic watershed type. The blood vessels and blood flow in the liver are similar to the distribution of rivers in the watershed. Under normal conditions, the distribution in the liver watershed is relatively fixed. The liver tissue in a certain watershed is supplied by multiple peripheral hepatic artery branches and portal vein branches and is drained by several hepatic veins surrounding the watershed. The blood flow in the liver is in equilibrium under normal circumstances, and when one or several blood vessels (inflow or outflow vessels) in the watershed are blocked, the blood flow will be out of balance, and the liver tissues of the blocked watershed will suffer "islet effect", which means that the liver tissues of the blocked watershed will be relatively ischemic or will experience blood stasis within a certain time window. However, to achieve a new balance of inflow and outflow of the liver blood, other blood vessels in the watershed will provide additional blood supply or new outflow tracts for the liver tissue in the blocked watershed. After the "islet effect", the blood flow of the liver will reach a new equilibrium state, and the distribution of watersheds will also change accordingly, forming a new distribution of liver watersheds, which is the liver dynamic watersheds theory.

\section{Acknowledgments}

Funding: None.

\section{Footnote}

Provenance and Peer Review: This article was a free submission to the Hepatobiliary Surgery and Nutrition. The article did not undergo external peer review.

Conflicts of Interest: All authors have completed the ICMJE uniform disclosure form (available at https://hbsn. amegroups.com/article/view/10.21037/hbsn-20-666/coif). The authors have no conflicts of interest to declare.

Ethical Statement: The authors are accountable for all aspects of the work in ensuring that questions related to the accuracy or integrity of any part of the work are appropriately investigated and resolved.

Open Access Statement: This is an Open Access article distributed in accordance with the Creative Commons Attribution-NonCommercial-NoDerivs 4.0 International License (CC BY-NC-ND 4.0), which permits the noncommercial replication and distribution of the article with the strict proviso that no changes or edits are made and the original work is properly cited (including links to both the formal publication through the relevant DOI and the license). See: https://creativecommons.org/licenses/by-nc-nd/4.0/.

\section{References}

1. Couinaud C. Anatomic principles of left and right regulated hepatectomy: technics. J Chir (Paris) 1954;70:933-66.

2. Shindoh J, Hasegawa K, Kokudo N. Anatomic resection of hepatocellular carcinoma: a step forward for the precise resection of the tumor-bearing portal territory of the liver. Ann Surg 2015;261:e145. 
3. Robles-Campos R, Brusadín R, López-López V, et al. A New Surgical Technique Variant of Partial ALPPS (Tourniquet Partial-ALPPS). Ann Surg 2021;273:e22-4.

4. van den Broek MA, Bloemen JG, Dello SA, et al.

Randomized controlled trial analyzing the effect of 15 or 30 min intermittent Pringle maneuver on hepatocellular damage during liver surgery. J Hepatol 2011;55:337-45.

5. Mine T, Murata S, Ueda T, et al. Contribution of

Cite this article as: Liu R, Wang Y, Zhang XP. Revisiting human liver anatomy: dynamic watershed theory. HepatoBiliary Surg Nutr 202 1;10(1):139-141. doi: 10.21037/hbsn-20-666 extrahepatic collaterals to liver parenchymal circulation after proper hepatic artery embolization. J Gastroenterol Hepatol 2014;29:1515-21.

6. Ikegami T, Shirabe K, Yoshiya S, et al. One-step reconstruction of the right inferior hepatic veins using auto-venous grafts in living-donor liver transplantation. Surg Today 2013;43:769-76. 